\title{
ANALISIS TAHAPAN PERKEMBANGAN MEMBACA DAN STIMULASI UNTUK MENINGKATKAN LITERASI ANAK USIA 5-6 TAHUN
}

\author{
Ana Widyastuti* \\ Pendidikan Bahasa Inggris/Pendidikan Bahasa Indonesia/Universitas Indraprasta PGRI
}

\begin{abstract}
Abstrak:Penelitian ini bertujuan untuk menganalisis tahapan perkembangan membaca dan stimulasi untuk meningkatkan literasi anak usia 5-6 tahun. Metode penelitian ini menggunakan penelitian deskriptif kualitatif. Adapun subjek penelitian adalah catatan hasil tahapan perkembangan membaca anak usia 5-6 tahun yang berjumlah 15 anak di TK Islam Assaadah Limo Depok. Sumber data adalah catatan guru hasil tahapan perkembangan membaca anak usia 5- 6 tahun. Hasil tersebut dikumpulkan, dianalisis dengan mengelompokkan pada tabel skor penilaian, selanjutnya dijumlahkan, serta yang terakhir dideskripsikan stimulasi apa yang tepat dan harus dilakukan guru sesuai dengan tahapan perkembangan membaca anak. Hasil penelitian menunjukkan bahwa rata-rata anak usia 5-6 tahun di TK Assaadah, masih sangat kurang optimal perkembangan membacanya. Penulis memberikan masukan terkait dengan hasil penelitian ini guna meningkatkan kemampuan literasi anak, khususnya anak 5-6 tahun di TK Islam Assaadah Limo Depok
\end{abstract}

Kata kunci: Tahapan perkembangan membaca, stimulasi, literasi, anak usia 5-6 tahun

\begin{abstract}
This study aims to analyze the stages of reading and stimulation development to increase the literacy of children aged 5-6 years. This research method using qualitative descriptive research. The subject of the study is the record of the development stage of reading children aged 5-6 years, amounting to 15 children in the Islamic Kindergarten Assaadah Limo Depok. The data source is the teacher's record of the reading progress of children aged 5-6 years. The results are collected, analyzed by grouping in the scoring table, then summed, and the last one described what kind of stimulation and should be done according to the teacher stages of child's reading. The results showed that the average child aged 5-6 years in kindergarten Assaadah, is still less than optimal development of reading it. The authors provide input related to the results of this study in order to improve the ability of children's literacy, especially children 5-6 years in kindergarten Islam Assaadah Limo Depok Keywords: Stages of reading development, stimulation, literacy, children aged 5-6 years
\end{abstract}

Keywords: Stages of reading development, stimulation, literacy, children aged 5-6 years

Alamat korespondensi: Jl. Nangka No. 58 C Tanjung Barat Jagakarasa, Jakarta Selatan 

PENDAHULUAN

Berdasarkan

Undang-Undang

Nomor 20 Tahun 2003 tentang Sistem Pendidikan Nasional, Pendidikan anak usia dini adalah suatu upaya pembinaan yang ditujukan kepada anak sejak lahir (0 tahun) sampai usia 6 (enam) tahun yang dilakukan melalui rangsangan pendidikan untuk membantu pertumbuhan dan perkembangan jasmani dan rohani agar anak memiliki kesiapan dalam memasuki pendidikan lebih lanjut.

Proses pendidikan bagi anak usia 56 tahun secara formal dapat ditempuh di taman kanak-kanak atau radiathul athfal. Melalui suatu proses pembelajaran sejak usia dini, diharapkan anak tidak saja siap untuk memasuki jenjang pendidikan lebih lanjut, tetapi yang lebih utama agar anak memperoleh rangsangan-rangsangan moral, bahasa, fisik-motorik, intelektual, sosial, dan emosi sesuai dengan tingkat usianya.

(Pratisti, 2008) menyatakan definisi anak usia dini dilihat dari batasan usia yaitu anak yang berusia a n t a r a $0-6$ tahun. (Susanto, 2011) juga menjelaskan bahwa anak usia dini termasuk dalam masa prasekolah dimana anak dalam rentang usia 4-5 tahun.
Menurut Sujiono, (2009) berpendapat bahwa pendidikan bagi anak usia dini adalah pemberian upaya untuk menstimulasi, membimbing, mengasuh, dan pemberian kegiatan pembelajaran yang akan menghasilkan kemampuan dan keterampilan anak. Salah satu upaya menstimulasi perkembangan anak untuk usia dini yaitu adalah stimulasi perkembangan bahasa. Belajar bahasa yang sangat krusial terjadi pada anak sebelum enam tahun. Pada rentang usia 3/4 sampai 5/6 tahun, anak mulai memasuki masa prasekolah yang merupakan masa kesiapan untuk memasuki pendidikan formal yang sebenarnya di sekolah dasar. Penelitian yang dilakukan oleh Susanto A. (2011) bahwa anak-anak membutuhkan tulisan untuk membantu mereka belajar membaca, mereka membutuhkan bacaan untuk membantu mereka belajar menulis, dan mereka membutuhkan komunikasi lisan untuk membantu mereka belajar membaca dan menulis.

Salah satu yang hendak dicapai dalam mengoptimalkan perkembangan anak usia TK atau 5-6 tahun yakni kemampuan membaca. Penilaian membaca pada anak usia 5-6 tahun bukan berdasarkan hasil, tetapi berdasarkan 
proses. Oleh karena itu, dinamakan dengan tahap perkembangan membaca. Kurangnya pengetahuan tentang apa saja tahapan perkembangan membaca ini mengakibatkan anak tidak mendapatkan stimulus yang tepat agar kemampuan membaca anak optimal. Karena kemampuan membaca adalah dijadikan bekal anak dalam menapaki ke jenjang pendidikan selanjutnya yaitu Sekolah dasar (SD).

Makna literasi mengalami perubahan dari waktu ke waktu. Sehingga didefinisikan dengan cakupan yang sangat luas (Ahmad, 2017). Nloome dalam (Suyanto, 20015) mengatakan bahwa literasi itu sifatnya dinamis dan relatif sehingga hanya dari suatu negara atau budaya ke negara atau budaya lain. Sementara itu menurut Graff dan Gee, literasi bukan suatu keterampilan atau fenomena tunggal. Literasi merupakan konsep yang tidak pernah berakhir.

Jadi pengertian dan penggunaan konsep literasi merupakan suatu kontinum, yakni mulai dari kemampuan membaca, kemudian membaca dan menulis, berpikir kritis dan berbahasa lisan yang dimanfaatkan untuk belajar sepanjang hayat baik di rumah, di tempat kerja, maupun dalam masyarakat.

Dalam Kamus Besar Bahasa Indonesia (KBBI) (Nasional, 2014) stimulasi adalah dorongan, rangsangan. Menurut (kebudayaan, 2015) "Stimulasi adalah pemberian rang-sangan pendidikan yang diberikan untuk mencapai kompetensi sikap, pengetahuan, dan keterampilan bagi anak usia dari lahir sampai dengan 6 tahun agar dapat tumbuh dan berkembang secara optimal. Stimulasi bahasa tulis berarti merangsang anak untuk mengenali, memahami, dan menggunakan simbol tertulis dari bahasa atau languagenya untuk berkomunikasi sesuai tahap perkembangannya.

Stimulasi adalah rangsangan pendidikan bagi anak usia dini permainan hingga produksi agar anak dapat tumbuh dan optimal perkembangannya (Rahim, 2007) keberhasilan proses stimulasi literasi dapat dipengaruhi bebe-rapa faktor yaitu(a)Faktor Fisiologis. Faktor fisiologis mencakup kesehatan fisik, pertimbangan neurologis, kelelahan, dan jenis kelamin. (b)Faktor Intelektual. Faktor IQ menjadi indikasi adanya remedial atau tidaknya proses belajar membaca dan menulis yang dialami oleh anak. 
(c)Faktor Lingkungan. Faktor lingkungan yang mempengaruhi kemajuan kemampuan literasi yaitu latar belakang dan pengalaman anak di rumah dan sosial ekonomi keluarga anak. (d) Faktor Psikologis. Faktor psikologis yang mempengaruhi kemajuan kemampuan literasi anak yaitu motivasi; minat; serta kematangan sosial, emosi, dan penyesuaian diri.

Stimulus baca tulis melalui bermain (Cox, 1999 :132) harus didasarkan pada hal-hal (a) Imersi. Anak-anak benarbenar tenggelam dalam lungkungan bahasa yang mereka pelajari. Oleh karena itu, sediakan lingkungan yang kaya akan bahan cetakan, alat peraga, buku-buku, tanda-tanda, tabel-tabel daan label-label. Anak-anak akan membaca keras-keras apa yang ada di sekelilingnya. (b) Demonstrasi. Agar suntuk atau tenggelam dalam proses belajar bahasa, anak-anak membutuhkan demonstrasi dari kegiatan orang di sekitarnya. Oleh karena itu, orang tua dan guru, sebaiknya menjadi model menulis, membaca dan berbicara bagi anak. (c) Keterlibatan. Proses belajar terjadi ketika anak secaraaktif terhadap apa yang mereka lakukan. Hal ini merefleksikan suatu perspektif konstruktif dari belajar dan mengajar. Anak- anak akan memilih sendiri apa yang mereka ingin baca dan kemudian mendramatisasi kannya. (d) Ekspektasi. Guru mengharapkan bahwa ia dapat mengajar dan anak-anak dapat belajar. Anak-anak harus memperoleh cukup kesempatan setiap hari untuk membaca dan menulis.guru harus selalu mendorong mereka untuk menjadi pembaca dan penulis. (e) Tanggung jawab Anakanak perlu belajar bertanggungjawab terhadap topik yang dipilih dan menemukan kesempatan untuk melakukannya. guru perlu menyediakan waktu dan tempat khusus bagi mereka. (f) Aproksimasi Anak-anak mengira-ira bentuk dan penggunaan bahasa. Orang tua dan guru mendorong anak untuk melakukan. Tipe dukungan inipenting daripada kesalahan yang dibust. Anakanak akan membuat prakiraa yang semakin rumit tentang penggunaan bahasa, tergantung pada tingkat perkembangan mereka. (g)Penggunaan. Apabila anak-anak belajar bahasa lisan dengan menyimak dan berbicara, mereka akan belajar bahasa tulis dengan belajar membaca dan menulis, serta menerapkan perkembangan pemahaman dan keterampilan mereka tentang bagaimana bahasa cetak berperan di kelas. Anak memiliki pengalaman dengan 
huruf-huruf.membaca dan menulis diintegrasikan ke dalam kegiatan seharihari dan dihubungkan dengan pengalaman anak. Anak belajar bagaimana menggunakan bahasa dalam situasi yang otentik dan bermakna. (h) Respon. Sebagaimana input dan pajanan dalam bahasa lisan, respon dalam bahasa tulis pun berperan bagi anak. Setiap pertanyaan yang diajukan merupakan materi yang bermakna dan termanfaatkan oleh anak dalam proses hipotesis dan pengujiannya. (Musfiroh, 2011)

Membaca adalah proses perubahan bentuk lambang/tanda/tulisan menjadi wujud bunyi yang bermakna. Oleh sebab itu, kegiatan membaca ini sangat ditentukan oleh kegiatan fisik dan mental yang menuntut seseorang untuk menginterpretasikan symbol-simbol tulisan dengan aktif dan kritis sebagai pola komunikasi dengan diri sendiri, agar pembaca dapat menemukan makna tulisan dan memperoleh informasi yang dibutuhkan. (Dalman, 2014)

Menurut Budiasih.,( 2001) "Membaca merupakan proses memperoleh makna dari barang cetak. Selanjutnya dikatakan bahwa ada dua cara yang ditempuh pembaca dalam memperoleh makna cetak, yaitu (1) langsung, yakni menghubungkan ciri penanda visual dari tulisan dengan maknanya, dan (2) tidak langsung, yakni mengidentifikasi bunyi dalam kata dan menghubungkannya dengan makna. Cara pertama digunakan oleh pembaca lanjut dan cara kedua digunakan oleh pembaca permulaan. Membaca permulaan merupakan kemampuan membaca pada tahap keberwacanaan. Secara teknis, pada tahap keberwacanaan ini, anak-anak diharapkan dapat menemukan sendiri sistem kebahasaan bahasa Indonesia melalui proses pembelajaran bahasa yang dilakukan berdasarkan konteks.

Beberapa pengertian di atas, dapat disimpulkan bahwa membaca adalah proses pembaca untuk memperoleh pesan melalui kata-kata atau perubahan bentuk lambang/tanda/tulisan menjadi bermakna dari barabg cetak. Dengan demikian anak akan menemukan sendiri sistem kebahasaan/ bahasa Indonesia.

Pperkembangan kemampuan membaca pada anak berlangsung dalam beberapa tahap (Widyastuti, 2017) (1) Tahap Fantasi (magical stage). Pada tahap ini, anak mulai belajar menggunakan buku. Ia berpikir bahwa buku itu penting, membolak-balik buku dan kadang-kadang anak membawa buku kesukaannya. Pada tahap pertama 
ini, guru harus menunjukkan model atau contoh tentang perlunya membaca, membacakan sesuatu pada anak, membicarakan buku pada anak. (2)Tahap Pembentukan Konsep Diri (self concept stage). Anak memandang dirinya sebagai pembaca, dan mulai melibatkan diri dalam kegiatan membaca, pura-pura membaca buku, memberi makna pada gambar atau pengalaman sebelumnya dengan buku, menggunakan bahasa buku meskipun tidak cocok dengan tulisan. Pada tahap ini, guru harus memberikan rangsangan dengan membacakan sesuatu kepada anak. Hendaknya anda memberikan akses pada buku-buku yang diketahui anak-anak, melibatkan anak membacakan berbagai buku. (3)Tahap Membaca Gambar (Bridging reading sttage). Pada tahap ini, anak menjadi sadar pada cetakan yang tampak serta dapat menemukan kata yang sudah dikenal, dapat mengungkapkan katakata yang memiliki makna dengan dirinya, dapat mengulang kembali cerita yang tertulis, dapat mengenal cetakan kata dari puisi, serta mengenal abjad. Pada tahap ketiga ini, guru membacakan sesuatu pada anak-anak, menghadirkan berbagai kosa kata pada lagu dan puisi dan memberikan kesempatan pada anak untuk menulis sesering mungkin. (4) Tahap Pengenalan Bacaan (Take-off reader stage). Anak mulai menggunakan tiga sistem isyarat (graphoponic, semantic, dan syntatic) secara bersama-sama. Anak tertarik pada bacaan, mulai mengingat kembali cetakan pada konteknya, berusaha mengenal tanda-tanda pada lingkungan serta membaca berbagai tanda seperti kotak susu, pasta gigi, atau papan iklan. Pada tahap ini guru masih tetap membacakan sesuatu untuk anak-anak sehingga mendorong anak membaca sesuatu pada berbagai situasi. Anda jangan memaksa anak membaca huruf secara sempurna. (5) Tahap Membaca Lancar ( Independent reader stage ). Pada tahap ini, anak dapat membaca berbagai jenis buku yang berbeda secara bebas. Menyusun pengertian dari tanda, pengalaman dan isyarat yang dikenalnya, dapat membuat perkiraan bacaan-bacaan. Bahan-bahan yang berhubungan secara langsung dengan pengalaman anak semakin mudah membaca. Pada tahap ini, guru masih tetap membacakan berbagai jenis buku pada anak-anak. Tindakan ini akan mendorong agar dapat memperbaiki bacaannya. Membantu menyeleksi bahan-bahan bacaan 
yang sesuai serta membelajarkan cerita yang berstruktur.

\section{METODE PENELITIAN}

Penelitian ini dikategorikan sebagai penelitian deskriptif kualitatif yang menerapkan langkah-langkah penelitian yang menghasilkan data deskriptif berupa kata-kata tertulis. Subjek penelitian dalam penelitian ini adalah catatan guru yakni proses tahapan perkembangan membaca anak usia 5-6 tahun berjumlah 15 orang. Hasil pengembangan yang berupa tindak lanjut dengan stimulasi ini akan diuji cobakan dalam pembelajaran di TK Islam Assaadah di kecamatan Limo Depok dan hasilnya akan dianalisis secara deskriptif.

\section{PEMBAHASAN}

Dari paparan hasil penelitian tahapan perkembangan membaca anak/siswa Usia 5-6 Tahun di TK Islam Assaadah Limo Depok yaitu (1)Jumlah anak pada perkembangan membaca tahap 1 Magical Stage yaitu 3 anak artinya pada tahap ini anak masih sangat kurang optimal perkembangan membacanya. Stimulus yang diberikan adalah guru harus menunjukkan model atau contoh tentang perlunya membaca, membacakan sesuatu pada anak, membicarakan buku pada anak. (2)Jumlah anak pada perkembangan membaca tahap 2 Self concept stage yaitu 5 anak artinya pada tahap ini anak masih kurang optimal perkembangan membacanya. Stimulasi yang diberikan yakni guru harus memberikan rangsangan dengan membacakan sesuatu kepada anak. Hendaknya memberikan akses pada buku-buku yang diketahui anak-anak, melibatkan anak membacakan berbagai buku. (3)Jumlah anak pada perkembangan membaca tahap 3 Bridging reading stage yaitu 4 anak artinya pada tahap ini anak berkembang cukup optimal. Stimulasi yang diberikan pada anak adalah guru harus memberikan rangsangan dengan membacakan sesuatu kepada anak. Hendaknya anda memberikan akses pada buku-buku yang diketahui anak-anak, melibatkan anak membacakan berbagai buku. (4)Jumlah anak pada perkembangan membaca tahap 4 Take-off reader stage yaitu 2 anak artinya pada tahap ini anak sudah baik atau optimal perkembangan membacanya. Stimulasi yang diberikan kepada anak yaitu guru masih tetap membacakan sesuatu untuk anak-anak sehingga mendorong anak membaca 
sesuatu pada berbagai situasi. (5) Jumlah anak pada perkembangan membaca tahap 4 Independent reader stage yaitu 2 anak artinya pada tahap ini anak sangat baik atau sangat optimal perkembangan membacanya. Stimulasi yang diberikan kepada anak yaitu guru masih tetap membacakan berbagai jenis buku pada anak-anak. Tindakan ini akan mendorong agar dapat memperbaiki bacaannya. Membantu menyeleksi bahan-bahan bacaan yang sesuai serta membelajarkan cerita yang berstruktur.

Jadi disimpulkan bahwa pengertian dan penggunaan konsep literasi merupakan suatu kontinum, yakni mulai dari kemampuan membaca, kemudian membaca dan menulis, berpikir kritis dan berbahasa lisan yang dimanfaatkan untuk belajar sepanjang hayat baik di rumah, di tempat kerja, maupun dalam masyarakat.

Dalam Kamus Besar Bahasa Indonesia (Nasional, Kamus Besar Bahasa Indonesia Edisi Keempat, 2014) stimulasi adalah dorongan, rangsangan. Menurut (kebudayaan, 2015) "Stimulasi adalah pemberian rangsangan pendidikan yang diberikan untuk mencapai kompetensi sikap, pengetahuan, dan kete-rampilan bagi anak usia dari lahir sampai dengan 6 tahun agar dapat tumbuh dan berkembang secara optimal. Stimulasi bahasa tulis berarti merangsang anak untuk mengenali, memahami, dan meng-gunakan simbol tertulis dari bahasa atau language-nya untuk berkomunikasi sesuai tahap perkembangannya. Rangsangan diberikan dalam berbagai bentuk, mulai dari permainan bentuk hingga produksi."

Jadi stimulasi adalah rangsangan pendidikan bagi anak usia dini permainan hingga produksi agar anak dapat tumbuh dan optimal perkembangannya.

Menurut Rahim, (2007) keberhasilan proses stimulasi literasi dapat dipengaruhi beberapa faktor yaitu(1) Faktor Fisiologis Faktor fisiologis mencakup kesehatan fisik, pertimbangan neurologis, kelelahan, dan jenis kelamin.(2)Faktor Intelektual Faktor IQ menjadi indikasi adanya remedial atau tidaknya proses belajar membaca dan menulis yang dialami oleh anak.(3)Faktor Lingkungan Faktor lingkungan yang mempengaruhi kemajuan kemampuan literasi yaitu latar belakang dan pengalaman anak di rumah dan sosial ekonomi keluarga anak.(4) Faktor Psikologis Faktor 
psikologis yang mempengaruhi kemajuan kemampuan literasi anak yaitu motivasi; minat; serta kematangan sosial, emosi, dan penyesuaian diri.

Sesuai yang dikatakan oleh Menueur Musfiroh, (2011) memaparkan bahwa: "Stimulasi yang paling baik diberikan pada masa anak-anak adalah melalui bermain., karena bermain adalah sumber perkembangan dan membentuk zone of proximal development (ZPD) (Vygotsky, 1967). Dalam bermain terjadi proses representasi simbolik, eksplorasi, eksperimentasi, penguasaan (mastery), penemuan (invention), ekspresi artistik, .menemukan manfaat (rewarding) dan cara yang tepat (apprioriate) untuk berinteraksi dengan orang lain (Bronson, 1993) Proses belajar, menurut pandangan kontruktivistik harus menekankan keterlibatan anak. Menurut pandangan ini, proses belajar haruslan menyenangkan bagi anak dan emmungkinkan berinteraksi secara aktif dengan lingkungannnya. Bermain merupakan media sekaligus cara terbaik anak untuk belajar. Dengan bermain itulah anak belajar melalui proses berbuat dan meyentuh langsung objekobjek nyata.anak tidak belajar banyak melalui interpretasi stimulus verbal (kata-kata) dari orang yang lebih dewasa."

Stimulus baca tulis melalui bermain (Cox, 1999 :132) harus didasarkan pada (1)Imersi. Anak-anak benar-benar tenggelam dalam lungkungan bahasa yang mereka pelajari. Oleh karena itu, sediakan lingkungan yang kaya akan bahan cetakan, alat peraga, buku-buku, tanda-tanda, tabeltabel daan label-label. Anak-anak akan membaca keras-keras apa yang ada di sekelilingnya. (2) Demonstrasi Agar suntuk atau tenggelam dalam proses belajar bahasa, anak-anak membutuhkan demonstrasi dari kegiatan orang di sekitarnya. Oleh karena itu, orang tua dan guru, sebaiknya menjadi model menulis, membaca dan berbicara bagi anak. (3)Keterlibatan Proses belajar terjadi ketika anak secaraaktif terhadap apa yang mereka lakukan. Hal ini merefleksikan suatu perspektif konstruktif dari belajar dan mengajar. Anakanak akan memilih sendiri apa yang mereka ingin baca dan kemudian mendramatisasikannya. (4) Ekspektasi Guru mengharapkan bahwa ia dapat mengajar dan anak-anak dapat belajar. Anak-anak harus memperoleh cukup kesempatan setiap hari untuk membaca dan menulis.guru harus selalu men- 
dorong mereka untuk menjadi pembacadan penulis.(5)Tanggung jawab Anak-anak perlu belajar bertanggungjawab terhadap topik yang dipilih dan menemukan kesempatan untuk melakukannya.guru perlu menyediakan waktu dan tempat khusus bagi mereka.(6) Aproksimasi Anak-anak mengira-ira bentuk dan penggunaan bahasa. Orang tua dan guru mendorong anak untuk melakukan. Tipe dukungan inipenting daripada kesalahan yang dibust. Anak-anak akan membuat prakiraa yang semakin rumit tentang penggunaan bahasa, tergantung pada tingkat perkembangan mereka.(7) Penggunaan Apabila anak-anak belajar bahasa lisan dengan menyimak dan berbicara, mereka akan belajar bahasa tulis dengan belajar membaca dan menulis, serta menerapkan perkembangan pemahaman dan keterampilan mereka tentang bagaimana bahasa cetak berperan di kelas. Anak memiliki pengalaman dengan huruf-huruf. membaca dan menulis diintegrasikan ke dalam kegiatan sehari-hari dan dihubungkan dengan pengalaman anak. Anak belajar bagaimana menggunakan bahasa dalam situasi yang otentik dan bermakna. (7) Respon. Sebagaimana input dan pajanan dalam bahasa lisan, respon dalam bahasa tulis pun berperan bagi anak. Setiap pertanyaan yang diajukan merupakan materi yang bermakna dan termanfaatkan oleh anak dalam proses hipotesis dan pengujiannya. Pertanyaan yang berkaitan dengan nama huruf, lafal, cara baca merupakan pertanyaan yang memerlukan respon segera. (Tadkirotun Musfiroh (2008: 12-16)

Membaca adalah proses perubahan bentuk lambang/ tanda/ tulisan menjadi wujud bunyi yang bermakna. Oleh sebab itu, kegiatan membaca ini sangat ditentukan oleh kegiatan fisik dan mental yang menuntut seseorang untuk menginterpretasikan symbol-simbol tulisan dengan aktif dan kritis sebagai pola komunikasi dengan diri sendiri, agar pembaca dapat menemukan makna tulisan dan memperoleh informasi yang dibutuhkan. (Dalman: 2014:7)

Menurut Zuchdi dan Budiasih (2001a: 50), "Membaca merupakan proses memperoleh makna dari barang cetak. Selanjutnya dikatakan bahwa ada dua cara yang ditempuh pembaca dalam memperoleh makna cetak, yaitu (1) langsung, yakni menghubungkan ciri penanda visual dari tulisan dengan maknanya, dan (2) tidak langsung, yakni mengidentifikasi bunyi dalam 
kata dan menghubungkannya dengan makna. Cara pertama digunakan oleh pembaca lanjut dan cara kedua digunakan oleh pembaca permulaan. Membaca permulaan merupakan kemampuan membaca pada tahap keberwacanaan. Secara teknis, pada tahap keberwacanaan ini, anak-anak diharapkan dapat menemukan sendiri sistem kebahasaan bahasa Indonesia melalui proses pembelajaran bahasa yang dilakukan berdasarkan konteks. “

Jadi membaca adalah proses pembaca untuk memperoleh pesan melalui kata-kata atau perubahan bentuk lambang/tanda/tulisan menjadi bermakna dari barabg cetak, maka anak akan menemukan sendiri sistem kebahasaan/ bahasa Indonesia.

Seperti yang dikemukakakn oleh Ana Widyastuti (2017) perkembangan kemampuan membaca pada anak berlangsung dalam beberapa tahap (1) Tahap Fantasi (magical stage) .Pada tahap ini, anak mulai belajar menggunakan buku. Ia berpikir bahwa buku itu penting, membolak-balik buku dan kadang-kadang anak membawa buku kesukaannya. Pada tahap pertama ini, guru harus menunjukkan model atau contoh tentang perlunya membaca, membacakan sesuatu pada anak, membicarakan buku pada anak. (2) Tahap Pembentukan Konsep Diri (self concept stage). Anak memandang dirinya sebagai pembaca, dan mulai melibatkan diri dalam kegiatan membaca, pura-pura membaca buku, memberi makna pada gambar atau pengalaman sebelumnya dengan buku, menggunakan bahasa buku meskipun tidak cocok dengan tulisan. Pada tahap ini, guru harus memberikan rangsangan dengan membacakan sesuatu kepada anak. Hendaknya anda memberikan akses pada buku-buku yang diketahui anak-anak, melibatkan anak membacakan berbagai buku. (3)Tahap Membaca Gambar (Bridging reading sttage). Pada tahap ini, anak menjadi sadar pada cetakan yang tampak serta dapat menemukan kata yang sudah dikenal, dapat mengungkapkan katakata yang memiliki makna dengan dirinya, dapat mengulang kembali cerita yang tertulis, dapat mengenal cetakan kata dari puisi, serta mengenal abjad. Guru membacakan sesuatu pada anakanak, menghadirkan berbagai kosa kata pada lagu dan puisi dan memberikan kesempatan pada anak untuk menulis sesering mungkin. (4)Tahap Pengenalan Bacaan (Take-off reader stage). Anak 
mulai menggunakan tiga sistem isyarat (graphoponic, semantic, dan syntatic) secara bersama-sama. Anak tertarik pada bacaan, mulai mengingat kembali cetakan pada konteknya, berusaha mengenal tanda-tanda pada lingkungan serta membaca berbagai tanda seperti kotak susu, pasta gigi, atau papan iklan. Pada tahap ini, guru masih tetap membacakan sesuatu untuk anak-anak sehingga mendorong anak membaca sesuatu pada berbagai situasi. Jangan memaksa anak membaca huruf secara sempurna. (5)Tahap Membaca Lancar ( Independent reader stage ). Pada tahap ini, anak dapat membaca berbagai jenis buku yang berbeda secara bebas. Menyusun pengertian dari tanda, pengalaman dan isyarat yang dikenalnya, dapat membuat perkiraan bacaan-bacaan. Bahan-bahan yang berhubungan secara langsung dengan pengalaman anak semakin mudah membaca. Pada tahap ini, guru masih tetap membacakan berbagai jenis buku pada anak-anak. Tindakan ini akan mendorong agar dapat memperbaiki bacaannya. Membantu menyeleksi bahan-bahan bacaan yang sesuai serta membelajarkan cerita yang berstruktur.
Untuk memberikan rangsangan positif terhadap berbagai potensi keberbahasaan anak di atas, maka permainan dan berbagai alatnya memegang peranan penting. Lingkungan termasuk di dalamnya, guru seharusnya menciptakan berbagai aktivitas bermain sederhana yang tampak akan tumbuh berkembang secara optimal.

Peraturan Mendikbud RI nomor 146 Tahun 2014 tentang Kurikulum PAUD (kebudayaan, 2015) pasal 8 menyatakan bahwa pentahapan usia dalam STPPA salah satu diantaranya adalah Tahap usia 4-6 tahun, terdiri atas kelompok usia: 4-5 tahun dan 5-6 tahun. Pada pasal 36 menjelaskan kegiatan PAUD meliputi layanan, waktu kegiatan, frekuensi pertemuan, rasio guru dan anak. Jenis layanan salah satunya adalah anak usia 5-6 tahun dapat melalui KB, TK/RA/BA, TPA dana tau SPS. (kebudayaan, 2015)

Di Indonesia, anak usia dini yang berusia 0-6 tahun, dalam pendidikannya, dikelompokkan berdasarkan usia, misalnya untuk 2-3 tahun masuk kelompok taman penitipan anak, usia 3-4 tahun untuk kelompok bermain, atau 4-6 tahun untuk taman 
kanak-kanak/raudatul athfal (Masnipal, 2013)

Berdasarkan paparan diatas, maka rumusan masalah adalah : "Bagaimana Analisis Tahapan Perkembangan Membaca dan Stimulasi terhadap Anak Usia 5-6 Tahun ?“

Adapun tujuan penelitian ini adalah untuk (1) Mengetahui tahapan perkembangan membaca pada anak usia 5-6 tahun (2) Bahan masukan untuk guru agar dapat memberikan stimulasi yang tepat sesuai dengan tahapan perkembangan membaca anak usia 5-6 tahun (3) memberikan wawasan, agar guru dapat mengetahui tahapan perkembangan membaca setiap anak dan mampu memberikan stimulasi yang tepat untuk mengoptimalkan literasi anak usia 5-6 tahun

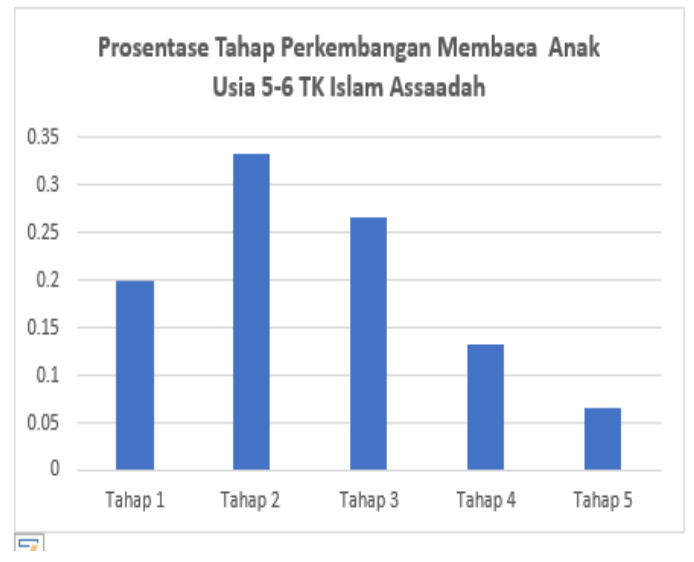

Gambar Prosentase Perkembangan Mebaca Anak Usia 5-7 TK Islam Assaadah
Dari paparan hasil penelitian tahapan perkembangan membaca anak/siswa Usia 5-6 Tahun di TK Islam Assaadah Limo Depok yaitu (1)Pada tahap 1 Magical Stage yaitu 3 anak atau $20 \%$ dari 15, yang artinya pada tahap ini anak masih sangat kurang optimal perkembangan membacanya. Stimulus yang diberikan adalah guru harus menunjukkan model atau contoh tentang perlunya membaca, membacakan sesuatu pada anak, membicarakan buku pada anak.(2)Pada tahap 2 Self concept stage yaitu 5 anak atau 33,3\% dari 15 yang artinya pada tahap ini anak masih kurang optimal perkembangan membacanya. Stimulasi yang diberikan yakni guru harus memberikan rangsangan dengan membacakan sesuatu kepada anak. Hendaknya memberikan akses pada buku-buku yang diketahui anak-anak, melibatkan anak membacakan berbagai buku.(3)Pada tahap 3 Bridging reading stage yaitu 4 anak atau 26,6\% dari 15 yang artinya pada tahap ini anak berkembang cukup optimal. Stimulasi yang diberikan pada anak yakni guru harus memberikan rangsangan dengan membacakan sesuatu kepada anak. Hendaknya memberikan akses pada buku-buku yang diketahui anak-anak, 
melibatkan anak membacakan berbagai buku.(4)Pada tahap 4 Take-off reader stage yaitu 2 anak atau 13,3\% dari 15 yang artinya pada tahap ini anak sudah baik atau optimal perkembangan membacanya. Stimulasi yang diberikan, yaitu guru masih tetap membacakan sesuatu untuk anak-anak sehingga mendorong anak membaca sesuatu pada berbagai situasi. (5)Pada tahap 4 Independent reader stage yaitu 1 anak atau $6,6 \%$ yang artinya pada tahap ini anak sangat baik atau sangat optimal perkembangan membacanya. Stimulasi yang diberikan kepada anak yaitu guru masih tetap membacakan berbagai jenis buku pada anak-anak. Tindakan ini akan mendorong agar dapat memperbaiki bacaannya. Membantu menyeleksi bahan-bahan bacaan yang sesuai serta membelajarkan cerita yang berstruktur.

\section{KESIMPULAN}

Simpulan dari paparan hasil penelitian ini adalah Karena stimulasi tahapan membaca anak secara umum belum optimal, implikasinya anak menjadi tidak termotivasi dan berminat untuk membaca. Jika guru memiliki pengetahuan, tentang tahapan perkembangan membaca dan stimulasi yang tepat, maka guru akan dapat meningkatkan kemampuan literasi dirinya dan anak didiknya. Hasil penelitian ini, dapat memberikan kontribusi bagi Pendidikan anak usia dini dengan stimulasi perkembangan anak yang tepat sesuai tahapannya serta dapat memberikan dampak positif dalam peningkatan kemampuan literasi, khususnya membaca di masa mendatang. Ucapan terimakasih kepada Ketua Yayasan Sirajussaadah Limo Depok Kepala Sekolah TK Islam Assaadah,Guru-guru TK Islam Assadah yang telah banyak membantu terselesaikannya penelitian ini

\section{DAFTAR PUSTAKA}

Ahmad, S. (2017). Teori Belajar dan Pembelajaran di Sekolah Dasar. jakarta: kencana prenada media grup.

Bronson, R. 1. (1993). Theory and Problems Of Operation Research. jakarta. 
Budiasih., D. z. (2001). Pendidikan Bahasa dan Sastra Indonesia di Kelas rendah. jakarta: depdikbud.

Dalman. (2014). Keterampilan Membaca. jakarta: raja grafindo.

kebudayaan, k. p. (2015). peraturan mendikbud RI nomor 146 tahun 2014 tentang kurikulum 2013 pendidikan anak usia dini. jakarta: kemendikbud.

Masnipal. (2013). Siap Menjadi Guru dan Pengelola PAUD Profesional,. jakarta: elex media komputindo.

Musfiroh, T. (2011). Menumbuhkembangkan Baca-Tulis Anak Usia Dini. jakarta: grmedia widyasarana indonesia.

Nasional, D. P. (2014). Kamus Besar Bahasa Indonesia Edisi Keempat. jakarta: gramedia pustaka utama.

Nasional, D. P. (2014). Kamus Besar Bahasa Indonesia Edisi Keempat . jakarta: Gramedia Pustaka Utama.

Pratisti, W. D. (2008). Psikologi Anak Usia Dini. jakarta: indeks.

Rahim, F. (2007). Pengajaran Membaca di Sekolah Dasar Edisi Kedua. jakarta: bumi aksara.

Sujiono, Y. N. (2009). Konsep Dasar Pendidikan Anak Usia Dini. jakarta: indeks.

Susanto, A. (2011). Perkembangan Anak Usia Dini. jakarta: kencana.

Susanto, A. (2011). Perkembangan Anak Usia Dini: Pengantar Dalam Berbagai Aspeknya. jakarta: kencana.

Suyanto, b. (20015). Metode Penelitian Sosial: Bergabai Alternatif Pendekatan. jakarta: Prenada Mediajakarta.

Widyastuti, A. (2017). perkembangan kemampuan membaca . jakarta: elex media komputindo. 